\title{
The effect of Zymomonas mobilis culture on experimental Schistosoma mansoni infection
}

\author{
0 efeito da cultura de Zymomonas mobilis na infecção experimental \\ por Schistosoma mansoni
}

\author{
Juliana de Fátima Macedo Santos ${ }^{1}$, Joelma Vasconcelos ${ }^{1}$, Joelma Rodrigues de Souza ${ }^{2}$, Eridan \\ de Medeiros Coutinho ${ }^{2}$, Silvia Maria Lucena Montenegro ${ }^{2}$ and Eulália Azevedo-Ximenes ${ }^{1}$
}

\begin{abstract}
C57Bl/10 male mice infected with Schistosoma mansoni were distributed into mixed, prophylactic and curative groups. A culture of Zymomonas mobilis was orally administered to mice. A $61 \%$ protection from the infection was observed in the curative group $(\mathrm{p}<0.05)$. Histopathological study of the livers and intestines showed similar results.
\end{abstract}

Key-words: Zymomonas mobilis. Schistosoma mansoni. Immunopotentiators. Experimental studies.

\section{RESUM0}

Camundongos C57Bl/10 do sexo masculino, infectados com Schistosoma mansoni foram distribuídos nos grupos misto, profilático e curativo. Cultura de Zymomonas mobilis foi administrada oralmente aos camundongos. Uma proteção de $61 \%$ foi observada no grupo curativo $(\mathrm{p}<0,05)$. Os estudos histopatológicos dos fígados e intestinos mostraram resultados similares.

Palavras-chaves: Zymomonas mobilis. Schistosoma mansoni. Imunopotenciadores. Estudos experimentais.

The immune response can be non-specifically stimulated by a number of agents ${ }^{912}$. One of these, Zymomonas mobilis, has already been studied ${ }^{6}$, and its antagonistic effects againstbacteria, fungi and protozoa are $\mathrm{known}^{67}$.

Although Z. mobilis has been used in several biological systems ${ }^{7}$, little is known about its action on helminthic infections. Schistosomiasis was studied on account of the severity the disease assumes in many cases and the organic deficiency it produces, making it one of the most serious public health problems.

The present study focused on the evaluation of host protection and the granulomatous lesions around Schistosoma mansoni eggs.

Six to eight week old C57Bl/10 male mice were obtained from the animal facilities of CPqAM-FIOCRUZ, Recife, PE, Brazil. Experimental and control groups were infected percutaneously with 100 cercariae (BH strain) shed from laboratory infected Biomphalaria glabrata.

A standard $10^{\circ} \mathrm{CFU} / \mathrm{mL}$ culture of Zymomonas mobilis was administered orally, at a dose of $0.3 \mathrm{~mL} /$ day $^{8}$.

For evaluation of the resistance to the S. mansoni infection and granuloma formation, the experimental groups were divided into prophylactic $(n=18)$ and curative $(n=17)$ in accordance with the guidelines for the administration of the $\mathrm{Z}$. mobilis culture, for 7 days before or 7 days after the infection, respectively. A mixed group $(n=15)$, receiving the bacterial culture before and after S. mansoni infection was also studied.

In control 1 group ( $\mathrm{n}=17)$, mice were infected in a similar way to the experimental group ${ }^{2}$ but did not ingest $\mathrm{Z}$. mobilis culture. In control 2 group $(n=6)$, mice were free of infection,

\footnotetext{
1. Department of Antibiotics of the Federal University of Pernambuco, Recife, PE, Brazil. 2. Department of Immunology, Centro de Pesquisas Aggeu Magalhães, Fundação Oswaldo Cruz, Recife, PE, Brazil.

Ethics Committee in Use of Animal (CEUA/FIOCRUZ) n ${ }^{0}$ : P0091-01

This work was supported by CNPq (Conselho Nacional de Desenvolvimento Científico e Tecnológico, Brazil).

Address to: Dra Silvia Montenegro. Department of Immunology, Centro de Pesquisas Aggeu Magalhães/CPqAM/Fundação Oswaldo Cruz. Av. Moraes Rego s/n, Cidade Universitária, 50670-420 Recife, PE, Brazil

Fax: 5581 3453-1911 - Tel: 5581 2101-2565

e-mail: silvia@cpqam.fiocruz.br

Recebido para publicação em 26/2/2004

Aceito em 25/8/2004
} 
but ingested the bacterial culture. In the placebo group $(n=5)$, the animals ingested culture medium without bacteria and acted as controls for the control 2 group.

The degree of protection was measured by infecting the mice and perfusion of the liver 60 days later. The number of worms recovered from each treated group of mice was compared with the non-treated control group, and protection was expressed as a percentage according to the following formula:

$$
\text { Protection }=\mathrm{C}-\mathrm{E} / \mathrm{C} \times \mathrm{100} \text {, where: }
$$

$\mathrm{C}$ - is the number of worms in the control group;

$\mathrm{E}$ - is the number of worms in the treated group.

Mice from the experimental and control 1 groups were sacrificed on the 60th day of infection and samples from the liver and intestines were fixed in 10\% buffered formalin, embedded in paraffin, sectioned at $5 \mu \mathrm{m}$ and stained with hematoxylin-eosin.

Statistical comparisons were made using Student's $t$ test, with a level of significance for the $p$ value set at 0.05 . All the experiments were repeated three times.

The total number of adult worms recovered was significantly lower in the curative group as compared to the control 1 group $(p=0.00049)$, resulting in $61 \%$ protection (Table 1$)$. In this group the immune response elicited byZ mobilis occurred after the S. mansoni infection. As the activation of the immune system begins on the third day, tends to peak on the fifth and decrease on the eighth day ${ }^{11}$, the immune response was very efficient, with death of the parasites occurring at the peak phase. The degree

Table1- Protection against Schistosoma mansoni infection in mice submitted to different therapeutic schemes with cultures of Zymomonas mobilis.

\begin{tabular}{lcc}
\hline Groups & Adult worm recovery & Protection \% \\
\hline Prophylactic $(\mathrm{n}=18)$ & $13.72 \pm 7.25$ & 24 \\
Curative $(\mathrm{n}=17)$ & $7.00 \pm 6.66^{*}$ & 61 \\
Control 1 (infected/non treated) $(\mathrm{n}=17)$ & $18.00 \pm 9.60$ & \\
\hline
\end{tabular}

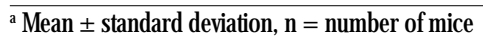

*Statistically significant in comparison to control 1 group ( $p=0.000490$ )

of protection reported is comparable to the immunity conferred by some schistosomiasis vaccine candidates ${ }^{3}$. Previous studies carried out with the immunopotentiators Corynebacterium parvum ${ }^{13}$ and levamisole ${ }^{10}$ using a similar methodology, demonstrated that the effects on the curative group treated with levamisole were similar to those obtained with the culture of Z. mobilis and different from the results with the use of $\mathrm{C}$. parvum. The variation in the effects of immunopotentiators depend on several factors such as: host immune status, severity of infection, dose, timing of drug administration and specific action of each one ${ }^{113}$.

Therefore, the prophylactic group was not significantly different when compared to the control 1 group, showing $24 \%$ protection against $S$. mansoni infection. In this group, which was treated before the infection, the immune response seemed to be much less efficient. On the other hand, in the mixed group a decrease in the number of adult worms was to be expected, since the onset of the curative treatment would provoke a secondary immune response. However, in this group, which involved a combination of the two treatments (prophylactic and curative), an exacerbation of the schistosomiasis infection was observed, since a larger number of adult worms was collected in comparison with the control 1 (infected and non-treated) group.

Studies with probiotic bacteria demonstrated that the dose and frequency of administration of these preparations influence the course of the stimulation of the immune system ${ }^{5}$. In this study, Z. mobilis culture dose administrated daily to the mixed group was similar to that given to the prophylactic and curative groups, but there was an increase in the frequency of administration, from 7 to 14 days. The observed increase in frequency may have led to an anergy state in this group, allowing a greater number of adult worms to be recovered at the time of the perfusion.

As far as histopathology was concerned, the lesions were similar in the experimental and control 1 groups. Hepatic changes were characterized by numerous periovular granulomas, mainly of the exudative type. Eggs and granulomas were seen in all the histological layers, in the three intestinal segments, though were more abundant in the walls of the jejunum-ileum.

No statistically significant difference was observed in the weights of the spleen and liver of the mice from the groups infected with S. mansoni. The same was true for the groups that were not infected (Table 2). The latter results in combination with the histopathological analysis of these organs in the control 2 (treated and non-infected) and placebo (non-treated and non-infected) groups, corroborate the conclusion reached by Fox ${ }^{4}$ that probiotics administered orally do not pose a threat of damage to the liver and spleen.

Table 2 - Average liver and spleen weights in the experimental and control groups.

\begin{tabular}{lcc}
\hline Groups & $\begin{array}{c}\text { Spleen weight }(\mathrm{g}) \\
\mathrm{M} \pm \mathrm{SD}\end{array}$ & $\begin{array}{c}\text { Liver weight }(\mathrm{g}) \\
\mathrm{M} \pm \mathrm{SD}\end{array}$ \\
\hline Prophylactic $(\mathrm{n}=18)$ & $0.252 \pm 0.05$ & $1.61 \pm 0.29$ \\
Curative $(\mathrm{n}=17)$ & $0.240 \pm 0.038$ & $1.62 \pm 0.21$ \\
Mixed $(\mathrm{n}=15)$ & $0.250 \pm 0.06$ & $1.47 \pm 0.25$ \\
Control $1(\mathrm{n}=17)$ & $0.250 \pm 0.06$ & $1.50 \pm 0.29$ \\
(infected/non treated) & & \\
Control 2 $(\mathrm{n}=6)$ & $0.105 \pm 0.017$ & $1.25 \pm 0.16$ \\
(non infected/treated) & & $1.24 \pm 0.01$ \\
Placebo $(\mathrm{n}=5)$ & $0.096 \pm 0.020$ & \\
(non infected/non treated) & & \\
${ }^{\mathrm{a}}$ Mean \pm standard deviation & & \\
\hline
\end{tabular}

\section{ACKNOWLEDGEMENTS}

We are grateful to Luiz Carlos Figueiredo and Roni Evêncio for technical support.

\section{REFERENCES}

1. Abath FGC, Coutinho EM, Montenegro SML, Gomes YM, Carvalho AB. The use of non-specific immunopotentiators in experimental Trypanosoma 
cruzi infection. Transactions of the Royal Society of Tropical Medicine and Hygiene 82:73-76, 1988.

2. Abath FGC, Montenegro SML, Carvalho AB. Modificação da técnica da bolsa de ar para mensuração da quimiotaxia "in vivo". Ciência e Cultura 38:1430-1433, 1986.

3. Dunne DW, Hagan P, Abath FGC. Prospects for immunological control of schistosomiasis. Lancet 345:1488-1492, 1995.

4. Fox SM. Probiotics: intestinal inoculants for production animals. Veterinary Medicine 83:806-829, 1998.

5. Isolauri E, Sutas Y, Kankaapaa P, Arvilommi H, Salminen S. Probiotics: effects on immunity. American Journal of Clinical Nutrients 73:444-450, 2001.

6. Lima OG. Sobre uma interessante e pouco conhecida publicação de Paul Lindner acerca do emprego terapêutico de Zymomonas mobilis Kluyver e Van Niel, 1936 ( Pseudomonas lindneri) . Revista do Instituto de Antibióticos 1:119-124, 1958

7. Lima OG, Schumacher IE, Araújo JM. Novas observações sobre a ação antagonista de Zymomonas mobilis (Lindner) (1928), Kluyver e Van Niel, (1936). Revista do Instituto de Antibióticos 8:19-48, 1968.
8. Lopes CAC, Lima OG. Efeitos obtidos com o emprego de culturas de Zymomonas mobilis var recifensis em pacientes portadores de enterocolites bacterianas. Revista do Instituto de Antibióticos 20:69-78, 1980.

9. Masihi KN. Cytokines and immunomodulators promising therapeutic agents. Parasitology Today 10:1-2 1994.

10. Montenegro SML, Teixeira KM, Coutinho EM, Abath FGC, Carvalho AB Efeitos de imunopotenciadores não específicos na infecção experimental pelo Schistosoma mansoni. I. Levamisole. Revista do Instituto de Medicina Tropical 33: 69-73, 1991.

11. Perdigon G, de Macias ME, Alvarez S, Oliver G, Holgado APR. Systemic augmentation of the immune response in mice by feeding fermented milks with Lactobacillus casei and Lactobacillus acidophilus. Immunology 63: 17-23, 1988.

12. Sarciron ME, Walbaum S, Petavy AF. Effects of Isoprinosine on Echinococcus multilocularis and E. granulosus metacestodes. Parasitology Research 81:329-333, 1995.

13. Teixeira KM, Coutinho EM, Abath FGC, Montenegro SML. Effects of nonspecific immunopotentiators in experimental Schistosoma mansoni infection. II. Corynebacterium parvum. Revista do Instituto de Medicina Tropical 38:359-363, 1996. 